\title{
Dinamismo evangelizador de la oración, según san Agustín
}

Los términos de oración y contemplación o vida activa y contemplativa tienen en el pensamiento agustiniano mayor expresión y profundidad que en nuestro lenguaje corriente. Su objeto formal son la eternidad y el tiempo; y su órgano de expresión son la razón «superior» y la «inferior». Por eso, el santo las define como Ciencia y Sabiduría. Y su dinamismo, en sentido descendente, se explica así: nuestra mente es una participación en el Verbo -lumen de lumine-; y ésa es la contemplación propiamente dicha, Sabiduría. Pero de ésta deriva la Ciencia, como nueva participación en la eternidad, y, por medio de ella, dependemos de la Verdad, qua subhaeremus intelligibili atque incommutabili veritati (por la que nos adherimos a verdad inteligible e inconmutable verdad) (De Trinit. XII, 3,3).

No se trata de dos facultades diferentes, sino de una sola con dos funciones, como de un matrimonio figurado y místico: erunt duo in carne una, sic de his dici possit: «Duo in mente una» (Ibidem, ibidem). Por ese dinamismo intrínseco se diferencian las actiones humanas de las actiones hominis. Éstas nos son comunes a los animales, mientras que las primeras nos separan de ellos. Las calificaciones de «superior» e «inferior», lo mismo que la asignación de la imagen divina propiamente dicha a la razón superior, nos muestran ya que la contemplación es superior a la acción. Y esto es general, y se refiere a toda la vida racional y no sólo a la vida espiritual, técnicamente entendida.

Esa comparación con el matrimonio permite a Agustín aplicar a las almas como a las viudas del texto 1Tim 5,5: nuestros hijos son nuestras obras de misericordia, las acciones «sociales» o externas que constituyen nuestra «biografía» - bios-, y por las cuales nos conocen los-demás. Y así se dice que la mujer se salvará por la generación de los hijos, esto es, por sus obras. Cada cual se define ante la sociedad por la «acción», por el modo con que se desenvuelve en la existencia temporal (De Trinit. XII, 7,11). Pero, así como la acción humana es sólo una acción del hombre - acción animal- cuando no participa 
en la contemplación de la verdad, así deja también de ser salvífica, cuando no va animada por la fe y por la caridad (Ibidem, ibidem). En este terreno, esto es, cuando damos carácter salvífico a la acción y contemplación, hablamos de la «vida espiritual» propiamente dicha. Porque el que no da carácter salvífico a sus obras, el que no practica la virtud o rectitud moral, dirigiendo su atención al Dios verdadero y se va dejando llevar por la triple concupiscencia o libido, de que habla san Juan (1 Ioan 2,16), va deteriorando la imagen de Dios y esculpiendo la imagen de la bestia, haciéndose más y más semejante a ella (De Trinit. XI, 7-11, 11-18).

Cuando vivimos según Dios, dirigimos la atención de nuestra mente a sus realidades invisibles, y por su eternidad, verdad y caridad debemos formarla. Pero una parte de nuestra atención racional, esto es, de la misma menté, tenemos que dirigirla al uso de las cosas mudables y temporales, pues, sin usarlas nada podemos hacer en esta vida. Mas no pretendemos conformarnos con este siglo (Rom 12,2), poniendo nuestro corazón en tales cosas y torciendo hacia ellas nuestro apetito de felicidad; por el contrario, todo lo que hacemos cuando utilizamos las cosas temporales racionalmente, hemos de realizarlo en la contemplación de los bienes eternos, que tratamos de adquirir, cuando utilizamos esas cosas, sin apegarnos a ellas (De. Trinit. XII, 13,21).

Como es obvio, hemos de fijar nuestra atención, ante todo, en la acción, esto es, en el uso de estas cosas temporales, aunque dentro de ese dinamismo espiritual y existencial de san Agustín. Él compara nuestra existencia con el torrente incesante:

Con la lluvia se engrosa el torrente y corre, se dilata, se envalentona, como símbolo de nuestra mortalidad. La humanidad va saliendo de la oscuridad, se congrega, emprende la marcha torrencial y luego vuelve a la oscuridad. Entre su aparición y su desaparición, va corriendo, pero pasando (Enarrat. in psal. 109,20).

La existencia humana es como el recital de un poema o himno; ninguna silaba puede detenerse, pues se cortaría el poema. Es preciso que cada silaba suene y se vaya extinguiendo, para que la siguiente pueda resonar y ser oída, manteniéndose asl el contexto y el sentido. Tal es la estructura esencial y temporal del mundo (Vera rel. 22,42-43).

Por ese dinamismo, muchos repiten que Agustín es un hombre moderno, en contraposición a los pensadores griegos, que contemplan un mundo esencial y estático. En efecto, también el hombre moderno, también nosotros vivimos en un dinamismo casi excesivo y enloquecedor. Y también nosotros tenemos que hacer nuestra la caritas agustiniana, que se dirige primeramente a Dios, pero que, en virtud de su propio dinamismo e impulso, ha de gastarse en obras de misericordia, de benevolencia y beneficencia con el prójimo. Es una mística del amor, una mística de la caridad, «pues el que ama a su prójimo, ve a Dios». Como hombres modernos, no podemos renunciar a ese dinamismo 
cristiano; pero, para que sea cristiano, tenemos que orientarlo y dirigirlo según el espíritu agustiniano, liberando ese dinamismo de algunas tendencias actuales heroicistas e idealistas, que no nos permiten ver el rostro de Dios en la faz de Jesucristo $(2 \operatorname{Cor} 4,6)$.

\section{LA ORACIÓN «ESPIRITUAL»}

El dinamismo cristiano supone que la vida espiritual proviene de la Sma. Trinidad por medio de Jesucristo. Proviene de la Trinidad, que es la fuente o principio de todo bien, pequeño o grande. Y proviene por medio de Cristo, ya que vivimos en el tiempo, en el pecado original y en sus consecuencias - poena peccati- Necesitamos, pues, la gracia de Cristo, la redención, la reconciliación, la filiación divina, que se nos proporciona en el bautismo, para recobrar esa vida que perdimos en el pecado original y que no podemos recuperar por medio de nosotros mismos, ni por medio de ángeles u otro cualquier medio, fuera de Cristo. Pero, dentro de nuestro lenguaje temporal y existencial, y ya que Cristo nos prometió enviarnos al Espíritu Santo y nos lo envió como representante suyo - como Espíritu suyo-, atribuimos la vida espiritual - la gracia, la caridad - al Espíritu Santo; y establecemos así que el principio - arché- de la oración cristiana ha de ser el Espíritu Santo, que ora en nosotros, que nos inspira la oración y que nos empuja hacia nuestra perfecciồn y total edificación.

Así descubrimos en esta «espiritualidad» dos funciones. La primera es inicial, fundamental, y aparece en el bautismo, por el que cobramos la filiación adoptiva de Dios, la divinización gratuita, que se opone al estado o situación de «pecado». Pero el pecado es algo más que una situación. Es también una energía, un impulso que nos inclina al mal - delectatio carnalis-, condicionando nuestra libertad, como un castigo que nos quedó al cometer el pecado original, en forma de ignorancia y de concupiscencia. Por eso, el Espíritu Santo tiene una segunda funció' que es la de superar esa energía del pecado, que nos tira hacia abajo, empujándonos hacia arriba. No hay superación ni confusión entre Cristo y el Espíritu en sus funciones, atribuidas por el hombre a cada uno, según el texto que Agustín utiliza continuamente: la caridad de Cristo se difunde en nuestros corazones por el Espíritu Santo, que se nos ha dado (Rom 5,5). Pero el lenguaje atribuye la caridad al Espíritu hasta el punto de que algunos teólogos identificaron ambos conceptos.

El Espíritu Santo nos impulsa hacia arriba, hacia Cristo, y cumple así la función del amor, que es llevar a cada ser hasta el grado de perfección que le compete. Es lo que llamamos «edificación». Y la realiza siempre, mientras no haya obstáculos u óbices que se le opongan. Lo cual se realiza, no sólo en los 
individuos, sino también en la Iglesia y en la humanidad entera, ya que todo progreso es obra del Espíritu, obra del amor edificante. En el régimen existencial en que vivimos, el amor se ejercita en obras de benevolencia y de beneficencia sociales. Al afirmar que la oración ha de ser espiritual queremos decir que ha de ajustarse, ya a la inspiración del Espíritu, ya a la situación temporal del hombre. Así como san Lucas trató de explicar la expansión y eficacia de la Iglesia por medio de ese Arché, que es el Espíritu Santo, así lo hizo también san Agustín; y concretamente desarrolló para la «vida monástica» una teología de Pentecostés. Porque confiaba que la eficacia de la vida activa o contemplativa, ha de venir del dinamismo dicho, de la fecundidad del Espíritu Santo. Una oración que no sea receptiva en ese sentido, no podrá llamarse «espiritual»: carecerá de sentido en el terreno cristiano. Esto no significa que debamos dar a todas nuestras acciones un carácter estrictamente espiritual, ya que en el Juicio Final se nos premian las obras por sí solas; y Cristo lava los pies a sus discípulos, para darles ejemplo. Para obrar movidos por el Espíritu Santo, no necesitamos proclamarlo, ni siquiera sentirlo: el mismo Espíritu gime en nosotros con gemidos ( $\operatorname{Rom} 8,26$ ), aunque nosotros no sepamos lo que pedimos. Lo importante es que la función perfectiva, terminativa o edificante de la caritas $($ Rom 5,5$)$ sea realmente nuestro motor o nuestro móvil.

Agustín insistió mucho en la eficacia de la caridad. Suponía que el amor no debe estarse quieto, y por eso decía humorísticamente: imostradme un amor ocioso! (Enarrat. in psal. 31,11,5). Un amor ocioso no es amor, sino una veleidad platónica. Por la misma razón estimaba que el celo es la consecuencia inmediata del amor: qui non zelat, non amat. Al identificar el amor universal con la gravitación universal (Cfr. Confess. XIII, 9,10), sabe que la función de la gravedad es empujar a cada cosa hacia su centro. Y, en efecto, el amor lleva a cada cual hasta su perfección, sino encuentra obstáculos que lo impidan: ésa es su labor edificante.

Mi amor es mi peso. Por él soy llevado a donde quiera que voy (Confess. XIII, 9,10).

Así llega a la fórmula más simple del mundo: ;Ama, et quod vis fac! (In Ioan. Epist. tract. 7,8).

¿Y por qué se atribuye esto tan sólo al Espíritu Santo? Como si se tratase de un lugar, que no es lugar, del que se dice que es tu Don. En tu Don reposamos, en Él gozamos de ti. Nuestro descanso es nuestro lugar. El amor nos lleva hasta él, y tu Espiritu bueno eleva nuestra humildad desde las puertas de la muerte... Mi amor es mi peso; por él soy llevado a donde quiera que voy. Por tu Don nos inflamamos y ascendemos: nos enardecemos y subimos (Confess. XIII, 9,10).

Nos hiciste, Señor, para ti; y nuestro corazón no reposará hasta que descanse en ti (Confess. I, 1,1). 
Es necesario proclamar ese dinamismo, ya que todos tenemos la sensibilidad espiritual de san Agustín; y tenemos que aprender de él, e imitarle en cuanto podamos. Hemos de ver, pues, la oración y la espiritualidad, no como filantropía, ideología, política, imperialismo o capricho, sino como obra espiritual, como edificación del Cuerpo de Cristo $(E f 4,12)$.

De ese problema fundamental proviene el otro de la eficacia de la oración. Agustín suponía que esa eficacia está siempre avalada por un seguro divino, aunque nosotros no veamos sus efectos. En cambio, nunca podremos estar seguros de tal eficacia, cuando nuestra oración no es «espiritual». En este terreno tenemos que comprobar por experiencia nuestros principios. Porque, aunque es verdad que Agustín distingue perfectamente la gratia Christi de la gratia creationis, no las separa dentro de su dinamismo y pensamiento orgánico. No podemos, pues, contentarnos con decir que poseemos una caridad sobrenatural e inconsciente, sino que debemos demostrarla, realizada en obras de misericordia. Y, por eso, ya desde el principio, las obras de misericordia, enseñanza, misiones, parroquias, apostolados, etc. han recibido el nombre de obras de caridad, ya que lo son o deben serlo. San Agustín aplicaba alegóricamente en este punto el texto del Génesis: en la creación -en el hombre, en las almas- están depositadas las razones seminales, que esperan su momento de desarrollo: el Espíritu se cierne sobre las aguas (Gén 1,2), sobre las almas. Y así como las aguas producen aves y peces, así las almas producen obras de misericordia. Para eso el Espíritu Santo produce en nuestros corazones el amor y el deseo.

Esta doctrina general es la que el Santo aplicará detenidamente a los religiosos, a aquellos que en la Iglesia piden un puesto entre los perfectos, entre los profesionales de la perfección. La doctrina de la oración, fundamental para todos los cristianos, es más urgente para esos religiosos, que van a convertirse en instrumentos del Espíritu Santo para la edificación del Cuerpo de Cristo. Si el Espíritu Santo es el Don de Dios por excelencia, la oración será también el «don del Espíritu Santo» por excelencia. Es el Espíritu Santo el que enciende en nuestros corazones esa llamita, ese deseo que san Agustín define como «alma o esencia de la oración» y que es el que inflama el corazón para subir a lo alto y recabar de Dios las bendiciones sobre la tierra, como Cristo nos prometió. San Agustín atribuía al Espíritu Santo la misma formación de las comunidades religiosas, animadas por la Teología de Pentecostés, que san Lucas ofrecía en los Hechos de los Apóstoles. El Espíritu reúne en uno las voluntades diferentes, que andaban por el mundo buscando en vano la felicidad y con esas voluntades amargas forma un solo mar (Cfr. Confess. XIII, 17, 2021; De mor. Eccl. I, 19,35: Ibidem, 25, 46-58).

Sacaremos en conclusión, tanto en el terreno individual como en el social, que muchos religiosos y comunidades no sienten la necesidad de edificar Igle- 
sia, y su espiritualidad se resiente de falta de eficacia, porque no reciben o no fomentan el «don de oración». Viceversa, los grupos cristianos fervorosos se sienten espoleados por el deseo y el celo propios de la caridad.

\section{EL «AGGIORNAMENTO»}

De los objetivos que el Vaticano II propuso a las Congregaciones religiosas, el primero parece ya firmemente fijado por los estudiosos: la espiritualidad de nuestro Fundador proclama una relación entre contemplación y oración, contemplación y acción, tiempo y eternidad, ciencia y sabiduría, razón inferior y razón superior. La dinámica, que los estudiosos han establecido en esa relación, reclama una superioridad de la contemplación sobre la acción, pero en determinadas condiciones. Y parece que, en realidad, no hemos tomado en serio esa superioridad, si pensamos en lo poco que se ha trabajado para realzar el valor y el sentido de la vida contemplativa, no ya sólo en nuestros monasterios de clausura, sino tampoco en nuevos intentos de revalorización.

Hubo un tiempo en que el tema de la «mística de san Agustín» se puso de moda dentro de la difusión general sobre la mistica. Los autores oponían una «mística psicológica» a una «mística sobrenatural de la contemplación infusa». En el fondo parecía una desviación de la «mística cristiana», que hallamos en la Sagrada Escritura y en la patrística; y, por eso, tales discusiones eran extemporáneas. Por lo mismo, fracasaban los estudios sobre una «mística de san Agustín», ya que se buscaba una «mística platónica», una mística carmelitana o un mero capítulo de teología dogmática. Cuando se vio que tales estudios no eran viables, decayó el interés; y el tema fue abandonado. Hace ya años que no se habla de la «mística de san Agustín», sino en contadas ocasiones y circunstancias. $Y$ la verdad es que se han hecho muy pocos esfuerzos por poner al alcance de nuestros monasterios de vida contemplativa unas doctrinas que desarrollen precisamente esa vida contemplativa, que casi siempre es ignorada o mistificada.

Pero tampoco se han hecho intentos nuevos y eficaces. El P. General anterior - P. Teodoro Tack - había lanzado la idea de organizar en alguna parte un ensayo de vida contemplativa. ¿Qué se ha hecho? Ahora procuramos, quizá, echar tierra encima, y que no se hable del asunto, pues parecemos avergonzados de nuestra ineficacia, como tantos otros Institutos religiosos. Es inútil repetir que la vida moderna está reclamando «centros de soledad» en todos los sentidos, y especialmente en el de la espiritualidad, para hacer frente a una de las dos grandes calamidades del hombre actual: incapacidad de vivir solo e incapacidad de vivir para el prójimo. Aparecen muchos centros de recogimiento; pero pocos, o casi ninguno, de recogimiento espiritual. Por lo mis- 
mo, un título como se ha dado a este Cursillo -Dinamismo evangelizador de la oración-, parece una ocasión propicia, no para echar tierra encima del problema de la contemplación, sino para proclamarlo en grupos y en sesiones solemnes. Lo cual, lejos de perjudicar a la vida activa y al apostolado, redundaría en su eficacia y valor. Los monjes de san Agustín, aunque educados para una vida contemplativa inicial, demostraron una eficacia y unos resultados apostólicos, que pocas veces se han visto en la Iglesia.

No debemos olvidar que, aunque nuestra colaboración y nuestras iniciativas sean requeridas, al fin y al cabo, la oración ha de ser un don del Espíritu Santo, que ha de tomar la iniciativa fundamental. Y en el mismo momento en que no se produzca esa dialógica, no sólo peligran la oración y la evangelización, sino también la vida misma de las Congregaciones religiosas. El Espíritu Santo cumplirá su función con los religiosos dentro de la Teología de Pentecostés. Y la acción del Espíritu dejará de ser una brisa suave y fresca de primavera, para convertirse en una tempestad que sacude los muros de los templos. No cesamos de hablar de la crisis actual; pero el Vaticano II nos puso en guardia frente a una crisis radical, y la reacción de los religiosos parece excesivamente débil para una tempestad semejante. La lucha de los primeros religiosos, que rodearon a san Agustín, fue dura, sangrienta, a veces mortal; y, sin embargo, el éxito fue imponente.

En la tarea de este Cursillo están comprometidas nuestra fe y nuestra caridad, ya que el problema es arduo y rebasa los límites de la misma vida religiosa. Se multiplican las propagandas sobre la oración, y cada vez se ora menos; se habla de las funciones envagelizadoras de la oración, y apenas sabemos cuáles son esas funciones. Por lo que el éxito no corresponde a tantas propagandas, a tantos trabajos, dineros y prcvidencias como empleamos. Según la inspiración agustiniana, los candidates al monasterio deberían comenzar a vivir una vida de contemplación, que sería vocación, selección, formación. Así comenzarían a vivir una oración que aspira a evangelizar. Pero, con frecuencia, esos candidatos son niños de edad y de espíritu, y ni siquiera han pasado por una «conversión de auténtica vocación». La vocación a edificar la Iglesia debería revelarse en una intención experimental y fervorosa, que casi siempre falta. Hemos inventado la fórmula de vida mixta para suplantar a la oración con la acción, y para suplantar a la oración espiritual con la oración filosófica, científica, psicológica, sociológica y técnica. Dentro de nuestro mundo secularizado, dedicamos tiempos a nuestra oración, oficial, como un paréntesis de la vida activa. La contemplación ha perdido su antiguo prestigio, y lo ha cedido a la oración trascendental de los indios o gurús. La vida activa se ha convertido en criterio para valorar la vida religiosa; y, si la situación no cambia, nuestra propaganda no es muy prometedora. Todos nos lamenta- 
mos; pero, ¿quién remediará esta situación? Quizá la tempestad del Espíritu Santo, el flagelo de Dios, la Gran Tribulación.

En la Epístola a Proba sobre la oración (Epístola 130), san Agustín pide, como condición perentoria, un alma desolada, que sienta necesidad de Dios, de Cristo, de la Iglesia. ¿Cómo va a dedicarse a edificar quien no se siente bien instalado, bien satisfecho en su situación? No es difícil buscar la oración, como se busca el yoga, para anestesiar, para olvidar, para estimular y calmar los nervios, esto es, para matar lo mejor que tenemos, la inquietud agustiniana. San Agustín reclamaba: Da amantem! (In Ioan. Evang. tract. 26,4). Dadme un amante, que sienta hambre y sed, etc... Pero la realidad es que muchos de nosotros no sentimos necesidad alguna del Espíritu Santo (Cfr. In Ioan. tract. 26,4). Dormitamos como gatos acurrucados junto al fuego.

Es difícil en esta situación comprender la espiritualidad agustiniana, que se siente crucificada entre un ahora y un después celestial. Es la nostalgia del eterno Sábado, con que el Santo interpretaba a san Pablo: Lo que ahora crees, después lo verás (Epist. 55,9,17). La vida presente es tiempo de necesidad y de fatiga, pero animado y fortalecido por la contemplación del Sábado futuro y eterno, por la fe y la esperanza. El deseo de Dios alimenta las fatigas de la evangelización y del apostolado. Lo último en la ejecución ha de ser primero en la intención. Quien ejerce el apostolado cristianamente, quien puede decir con san Pablo: « ¿Ay de mí, si no evangelizare!», quien evangeliza por el impulso del Espíritu Santo y no por capricho o gimnasia espiritual, ha de sentir esa nostalgia del eterno Sábado, esa «dolencia del corazón inquieto».

Aunque a veces planteamos el problema de la evangelización buscando en la oración un «Dinamismo evangelizador», en realidad, podríamos decir que no hay problema, ya que toda oración auténticamente cristiana entra en ese dinamismo evangelizador. Distinguimos entre acción y contemplación, entre vida activa y contemplativa, pensando en sus objetos formales, según el criterio aristotélico, pero en realidad se trata de una oración evangelizadora o de una evangelización orante. Por la diferencia que media entre ambas, podemos optar por una preponderancia de la una o de la otra. Pero en ambos casos la oración y el apostolado son tan inseparables que basta separarlos para privarlos de sentido y de valor.

\section{MARTA Y MARÍA; LÍA Y RAQUEL}

Marta y María son dos hermanas. Simbolizan las dos vidas: la activa y la contemplativa. Juntas, constituyen la casa en que se hospeda agradablemente Jesucristo. Ambos géneros de vida son officia, profesiones. El Señor declara que la actividad de Marta es buena; pero la de María es mejor. ¿Por qué? Por- 
que Marta se afana nerviosa, mientras María descansa en la palabra de Cristo. Marta quiere abarcar una. multiplicidad - circa multa -, que dispersa, mientras María se concentra en la unidad - circa unum-(Serm. 103, 2 y 3).

Cristo no manda a María levantarse para ayudar a su hermana, pero tampoco manda a Marta sentarse a escuchar la palabra. Sólo corrige el nerviosismo de Marta, suponiendo que su labor es necesaria en ese momento (Serm. 104, 2-3). La actividad de María sigue siendo mejor y nunca se interrumpirá; mientras que la de Marta depende de la necesidad. Al cesar la necesidad, cesa la actividad; al cesar la miseria, cesa la misericordia, aunque en este mundo nunca se acabarán (Serm. 179, 4 y 5). Hay que ocuparse en la necesidad: antequam perveniamus ad unum, multis indigemus (Serm. 255, 6,6). Pero hay que llevar en la intención la unidad: unum nos extendat, ne multa distendant (Ibidem, ibidem). La extensión de san Agustín en el Contra Faustum, sobre esta materia (Cfr. Contra Faust. 22, 54-58), nos da a entender la importancia que atribuía a esta meditación.

Algo semejante ocurre con las esposas de Jacob, Lía y Raquel, con el mismo sentido. Además, aquí pone Agustín gran calor, como alegando experiencia de «intelectual», condenado a trabajos forzados. Lía ha de ser antepuesta por su «fecundidad», por la necesidad temporal, si bien Raquel es más hermosa y amable por sí misma. El candidato, que viene al monasterio, ama a Raquel; pero tiene que aceptar primero a Lía, si Dios, en la figura de Labán, lo dispone. Queda a veces Raquel relegada a la vida eterna, y así hay que unirse a Lía por amor a Raquel. Pero como Raquel sería estéril sin la referencia a Lía, surge una santa envidia que se evidencia en el símbolo de las mandrágoras de la fecundidad (De consensu. Evang. I, 4,7).

Vemos que, cuando Agustín abandona la mística platónica, tiene que renunciar a ver a Dios en este mundo; y entonces la visión beatífica cobra carácter escatológico: es la vida eterna. Pero la contemplación se conserva como «nostalgia», «deseo», «amor»; y hay ciertos momentos que son como «aspersiones» o rociadas para suavizar la travesía y la sed de este desierto. Por eso, se conserva la vida contemplativa como preámbulo y anticipación de la vida eterna. El llamado «éxtasis de Ostia» era una contemplación en que Agustín deseaba saber cómo será la vida de los santos (Confess. IX, 10,23). Es un tema frecuente en la contemplación agustiniana. Y el Espíritu Santo impulsa y mueve, no sólo a los individuos, sino a la Iglesia entera a vivir esta vida contemplativa anticipada, si bien la Iglesia nunca podrá descansar en este mundo, por las necesidades que el mundo le presenta (Cfr. La Bonnardière, A-M: Marthe et Marie, figures de l'Église d'après S. Augustin-La vie spirituelle, 36 (1952) pp. 408-427).

Hay, pues una contemplación perfecta, o visión beatífica propia de la vi- 
da eterna (Cfr. De Trinit. I, 8,17). Pero hay otra contemplación imperfecta, propia de esta vida, y la vivimos ya por la fe (Lía), ya por la esperanza (Raquel). Y de tal modo, que la contemplación perfecta es la continuación de la contemplación imperfecta, sin solución de continuidad. Y, por otra parte, esa visión beatífica es el «galardón», la recompensa de esta contemplación imperfecta de la fe (De Trinit. I, 10,20).

Felizmente se han ido apagando las discusiones entre los teólogos que reducían la mística a un capítulo de teología, y los que presentaban la mística como una serie de fenómenos psicológicos. Tales discusiones, que aludían a la llamada contemplación infusa, inconsciente, imperceptible y sólo manifiesta en ciertos fenómenos psicológicos, dañaron no poco a la mística, sembrando una gran confusión. Se reclamó la vuelta a la mística de los Padres; pero la confusión subsiste, aunque dentro de una mayor apertura e independencia. Por lo que toça a san Agustín, las discusiones se han sobreseído, y la situación es más clara y profunda.

Dentro de la mística agustiniana del Totus Christus o per Christum hominem ad ChristumiDeum, caben todos los tipos de mística cristiana: mística de Cristo como esposo, como crucificado, como liturgia, como Logos, como Eucaristía, o como noche de Dios. Przywara destaca tres tensiones que pueden vivirse con independencia o armonizarse. Hay una mística apegada al Cristo evangélico en variadas formas de aplicación de los sentidos y aplicación de las potencias; y hay una mística del Cristo eclesiástico, que pervive en la Iglesia. Es preciso actualizar a Cristo, traducirlo, interpretarlo, como lo reclama el Vaticano II. Del mismo modo, hay que una mística del Cristo personal, como cuando decimos con san Pablo: Cristo vive en mí o yo vivo en Cristo, objetivamente hablando. Y hay una mística de Cristo vivida en el culto, que no se reduce a folklore, sino al sentido profundo de los símbolos y sacramentos. Es el Cristo-Iglesia, un solo cuerpo. Cristo está, no sólo en mí, sino también en la Iglesia. Finalmente hay una mística del Cristo kenótico, del Cristo abatido, que se anonadó a sí mismo hasta la muerte de cruz. Esta mística posee hoy gran prestigio en la lucha en favor de los marginados, pobres, enfermos, menospreciados.

El calor que Agustín pone en el Contra Faustum, para plantear el problema de Jacob en su relación con Lía y Raquel, reclama una atención especial. Por un lado parece la continuación del libro XIII de las Confessiones; por otro lado, se amplía la visión introduciendo a las dos esclavas de Labán, Zelfa y Bala, que también dan hijos a Jacob. En principio, Lía es el trabajo; y Raquel, la visión (Contra Faust. manich. 22,52). Y se supone que los que ingresan en el monasterio buscan el sosiego de la contemplación (Ibidem, ibidem). $\mathrm{Y}$, sin embargo, supone también Agustín que el caso de Jacob es casi una nor- 
ma general, o, por lo menos, muy frecuente: se obliga a los candidatos a desposarse con el trabajo, antes que con la contemplación (Ibidem, ibidem). Parece, pues, que en el amor a Raquel hay un tanto de ilusión, pues la realidad de la vida presente, como desposorio con Lía, parece inexcusable (Ibidem, ibidem).

La una es amada, la otra tolerada. Mas la que es tolerada se antepone por su fecundidad y se hace amar por sus hijos, cuando no por si misma. Porque la actividad de los justos produce un fruto máximo en la predicación del Evangelio (Contra Faust. manich. 22, 54).

Había, pues, en el punto de partida un tanto de ilusión platónica, ya que, al cabo de los siete años de trabajo, Jacob tiene que esperar otros siete, que corresponden a los siete dones del Espíritu Santo (Cfr. De serm. Domin. in monte). Y lo más grave es que al fin de este segundo plazo, la sabiduríaRaquel aparece como una Fata Morgan, un espejismo escatológico (Contra Fausto manich. 22, 52).

Raquel es hermosa, pero quisiera dar a luz y no puede... La vida que se entrega al afán de la contemplación... desearía desentenderse de todo negocio, pero entonces se hace estéril. Al aumentar el «ocio», con el que se enardecen los deseos de contemplación, no se ajusta a la debilidad de los hombres, que piden ayuda en sus necesidades. $Y$, como Raquel quiere ser fecundada..., y ve a su hermana llena de hijos por sus trabajos de acción y pasión, se lamenta de que los hombres corren hacia ella (Ibidem, 22, 54).

Esta era la respuesta precisa a la Epístola 5 de Nebridio, cuando protestaba por el cambio de óptica de Agustín. La ilusión platónica se desvanece, y el que ingresa en un monasterio se encuentra, quizá, con lo que no esperaba: un nuevo método. Tiene que sujetarse a la fe, ejercitarse en la virtud y consolarse nostálgicamente con una visión beatífica, que es escatológica (Ibidem, 22, 53).

Es, sin embargo, hermosa esta postura. Porque, por un lado, se mantiene en el «orden» temporal como conviene; y, por otro, la nostalgia del eterno Sábado cumple su misión-función, animando y embriagando a veces al obrero apostólico, cansado del trabajo y de la familia de Lía.

Curiosamente Agustín aprovecha su propia teoría de pasar de lo visible a lo invisible. Raquel, buscando la fecundidad, entrega a Jacob su esclava Bala, que significa vieja, esto es: de la vieja, cargada de imágenes corporales y empíricas, ha de sacar Jacob una escala para subir a las cosas incorporales; y de ese modo retorna a un método ya consagrado, a un orden previamente establecido (Ibidem, 22, 54). Volvemos, pues, no por casualidad, sino por principio, al método de la analogía, para buscar a Dios por espejo y enigma, es decir, en sus imágenes y semejanzas. Pero se trata de una necesidad, que no satisface al corazón, ya que Raquel sigue siendo infecunda.

A su vez Lía trata de multiplicar sus hijos, sus obras, y entrega a Jacob a 
su esclava Zelfa. Y como Zelfa significa boca abierta, plantea el problema de la predicación del Evangelio (Ibidem, 22, 55). Descubrimos aquí la intención agustiniana de que, no sólo clérigos, sino también los religiosos predicasen el Evangelio de diferentes modos, como el mismo Santo se lo repetía a Leto en la famosa Epistola 243. De ese modo aprovecha el episodio de las mandrágoras para recomendar el buen olor de Cristo. Saca en limpio que la única propiedad específica de las mandrágoras es su buen olor, y concluye que Raquel se siente estimulada, como celosa, por la fama popular que Lía consigue con su fecundidad y con su familia numerosa, con sus obras y trabajos (Contra Faust. manich. 22, 42, 55 y 56).

No es difícil comprender a Agustín. La buena fama, que sus monjes habían conseguido en África, es su honra (De opere monach. 28, 36). El deseo de fecundidad es el hijo mayor de Lía, que es el que encuentra las mandrágoras; y esto significa que todo contemplativo ha de cultivar un deseo, no sólo de su propia perfección, sino también de su servicio a la Iglesia. Ésas son las mandrágoras que pasan de Lía a Raquel. El celo de la gloria de Dios saca ya a Raquel de su ensimismamiento contemplativo. Así Agustín entiende ahora que los que obligan a los hombres, hábiles para los negocios, a pasar de la vida contemplativa a la activa, hacen bien en ese su caso, y eso es lo que predica a los monjes de la Capraria, en su carta a Eudoxio (Epist. 48). De ese modo, la contemplación en este mundo queda subordinada a la acción y propagación de la Iglesia, a la edificación (Contra Faust. manich. 22, 57).

Por eso, Lía se queja con razón porque le quitan las mandrágoras y $\mathrm{Ra}$ quel devuelve su esposo a Lía. En todo esto aparece una intención autobiográfica de Agustín, pero de la que saca una doctrina general (Ibidem, 22, 58). Todo este largo capítulo es la filosofía y la teología de la historia del monacato de Agustín, tal como él podía escribirlas. Los amigos del Santo habían ingresado como contemplativos; pero se habían ido esparciendo como obispos, clérigos y como dirigentes de un movimiento o de reforma, que estaba transfigurando el rostro de la Iglesia africana. Pero el amor de Agustín a Raquel, a la contemplación, es tan fuerte, que, a pesar de convertirlo en una añoranza del eterno Sábado, le da tanta fuerza, que le asigna un doble carácter: la acción sería demasiado dura sin la suavidad de la contemplación; además, Raquel es capaz de dar a luz alguna que otra vez por sí misma, alcanzando la contemplación tan perfecta, que pueda intuir el texto: En el principio era el Verbo.

Fausto objetaba que no podía comprender esta doctrina del monacato y de la virginidad, que le parecía contraria al Evangelio y a la razón (Contra Faust. manich. 30, 4). 


\section{LA MÍSTICA DE LA CARIDAD}

El abandonar la «mística agustiniana» en el sentido de mística platónica, no debería significar el abandono de la auténtica «mística agustiniana», que es una mística de la caridad. Esa mística va tan ligada a la vida religiosa que, prácticamente, se identifica con ella. Bastará recordar que, cuando Agustín organizó en Tagaste su monasterio, Nebridio protestó, porque Agustín se dedicaba a evangelizar a sus conciudadanos en lugar de escribir cartas sobre Platón, Plotino y Cristo (Cfr. Epístolas 5 y 6).

Pero el problema de la mística de la caridad no debe consistir en reducir o banalizar el tema de la caridad, sino en dilatar y profundizar el tema de la mística. Sabido es que san Agustín utilizaba el término mística para designar un sentido figurado, la alegoría, el símbolo, el tipo, algo que anuncia una realidad diferente, y que, dentro del pensamiento del Santo, corresponde a su tendencia de ir «de lo visible a lo invisible», como método existencial y universal. Ya se ve que tal modo de ver se acerca al término sacramento, por su conexión con la gratia Christi, o con la eficacia del símbolo. Así entendemos desde el primer momento que la contemplación agustiniana se funda en lo visible, en un paso de lo visible a lo invisible, ya con el método de las ascensiones - como se ve en la llamada «visión de Ostia»-, ya con otros métodos dialécticos y filosóficos, como por ejemplo, en los libros La música, El orden, La extensión del alma, etc...

$\mathrm{Al}$ concretarnos al terreno propiamente espiritual, y más concretamente al monástico tendríamos que estudiar cómo formaba Agustín a sus monjes; tema que está poco estudiado, pero que es suficientemente conocido, ya que el mismo Agustín nos habla de la «preparación y formación de sus gentes» en materia de pobreza, de castidad y de conocimiento de las leyes y usos eclesiásticos. De otras dotes apenas nos habla, pero nos son conocidas, ya que casi todos sus primeros compañeros religiosos provenían de la Administración romana y tenían una cultura y habilidad para los negocios, ya probada en sus ejercicios anteriores. Aun así, tenemos dos documentos que significan ya un estudio preliminar. El primero es la Epistola 243 a Leto, donde se habla de la vocación y del noviciado. El segundo es la Epístola 48 a Eudoxio en la que invita a los monjes a mantenerse activos en la contemplación mientras no los llame la Iglesia al apostolado militante, y entregarse al apostolado en el momento en que la Iglesia los llame. En el libro de Las 83 cuestiones tenemos un pequeño fichero, que Agustín utilizaba para responder a las demandas de sus candidatos. En todos los casos el pensamiento de Agustín es formar hombres para la Iglesia.

Es obvio que, al iniciarse la lucha pelagiana, el tema de la gratia Christi 
había de ocupar el centro de las discusiones de un modo muy particular, dado que todavía no se habían marcado las diferencias o separaciones entre el orden natural y el sobrenatural. San Agustín distingue perfectamente ambos órdenes, y hubo de poner en guardia sin cesar a los que ingenuamente se dejaban engañar por los pelagianos, confundiendo la gratia redemptionis con la gratia creationis. En cambio, el que no se hubiera acentuado la separación, le ofrecía la ventaja de presentar las cosas visibles como efectos de las invisibles. Así, las llamadas obras de misericordia - benevolencia y beneficencia- se presentaban como efectos de una gracia sobrenatural, y eran la revelación de esa misma gracia. No se podía pensar en una gracia sobrenatural que no producía nada visible y que no podía responder a la demanda evangélica: Por sus obras los conoceréis ( $M t 7,16$, y 20). En este sentido tenemos, quizá en el fondo, una confesión de que Agustín prefería las obras espirituales a las corporales; pero tenemos también una teoría general sobre el trabajo mismo como obra de misericordia y sobre la necesidad de dar buen ejemplo apostólico a los cristianos.

Es, pues, claro el doble carácter - activo y pasivo- de esta caridad, que constituye, al fin, una mística. El que, por medio de la gracia divina, DiosCristo tenga siempre la iniciativa de la espiritualidad, asigna a ésta un carácter inicialmente pasivo. Pero ese carácter nos pasa desapercibido, como objeto de la fe; $y$, en cambio, nos vemos obligados a una contribución, que para nosotros es actividad pura y simple. Nuestras obras son nuestras, aunque las realicemos movidos por la gracia, tal como nos lo explica Agustín, diciendo que el pan nuestro de cada día es nuestro. Ulteriormente, por el hábito y la tensión interior, la espiritualidad vuelve a ser pasiva, en cuanto que, de las profundidades del alma, removidas por el corazón y la gracia, van saliendo los impulsos, que constituyen ya una segunda naturaleza, tal como la vemos en los santos.

Y puesto que ese proceso se desarrolla en san Agustín dentro de Cristo, la fórmula mística de san Agustín dice: Por Cristo hombre a Cristo Dios. En el libro La Trinidad Agustín nos explica en qué consiste la ciencia de Cristo y la sabiduría de Cristo. Él es nuestra ciencia y nuestra sabiduría; y en Él se realiza y logra la función de la mística cristiana: la caridad, por la que llegamos a la unidad, sin salir del mismo Cristo. La función de la mística tiene en común con otras formas de religiosidad el centrarse en el primer Mandamiento: amar a Dios y al prójimo con perfección. Pero, si Agustín proponía ya ese ideal en el libro Las costumbres de la Iglesia, el ideal tenía que irse depurando e intensificando con la doctrina del hombre como imagen de Dios y con el régimen de dispensatio temporalis, que vivimos los hombres en la tierra. De ese modo el término obvio y normal de la religiosidad agustiniana es una mística. Pero no será una mística de la interioridad, en la que buscamos a Dios en nuestro inte- 
rior y en nuestro interior reposamos; y tampoco será una mística de la Nada, en la que se renuncia al Todo. La mística agustiniana es, pues, diferente de la mística psicológica, que se organiza en la Edad Media; y es también diferente de la que hallamos en el Areopagita, en Eckhart y en san Juan de la Cruz.

Cristo es el único necesario, la Vida, a la que sirven Marta y María (Serm. 255, 6); el Espíritu de Cristo, que edifica la Iglesia, es el soplo místico que alienta en esta mística de la caridad, porque existe unidad de la caridad. Al mismo Espíritu pertenece la comunidad en la que nos convertimos en unidad con el Cuerpo del Hijo Único de Dios (Cfr. Serms. 71, 17, 19, 28; Serm. 142, 7). Dada la relación entre acción y contemplación, toda obra de caridad es edificación de la Iglesia, mística de la caridad. Przywara nos muestra cómo todas las formas concretas de la mística cristiana acaban dentro de la fórmula agustiniana: Por Cristo hombre a Cristo Dios; y al mismo tiempo tienen en ella su norma doctrinal y experimental: conjugar la intimidad que reclama la mística con la distancia y respeto que reclama también la mística cristiana. La mística ha de conjugar el osculetur me osculo suo con el noli me tangere (Cfr. Przywara, E: Ringen der Gegenewart; Ausburg 1929; I, 471 y 472ss).

Hoy aparecen en la Iglesia tendencias místicas contrapuestas y en tensión. Por un lado, aparece la mística que desafía al mundo con la locura de la cruz y del pesebre, y proclama la impotencia del hombre como potencia de Dios. Es la teología y la mística de la humildad, de la pobreza, de la liberación, de la Buena Nueva y de la proximidad del Reino de Dios. En sentido opuesto se proclaman una teología y una mística del Cristo Pantocrátor, Ideal de Progreso, de la Iglesia como Sociedad Perfecta, Sociedad de Poder, Ideal de Progreso, sacralización de la naturaleza, del humanismo, etc. Mientras unos hablan del pesebre y de la cruz, otros hablan de Cristo amigo de publicanos y pecadores. Poco costaría ordenar en las obras de san Agustín esos tipos de mística cristiana, ya aislados ya en convergencia en el Totus Christus. Es una cartera preciosa de doctrina, que las almas contemplativas podrían utilizar para su formación y para el ejercicio de su vida contemplativa.

Se han hecho numerosos ensayos para proporcionar actividad a las Comunidades de vida contemplativa. Pero las motivaciones son muy dudosas; y suscitan numerosas discusiones. 'Se debe en gran parte a la extremada pobreza en que habían caído dichas Comunidades, amenazadas de extinción por falta de medios o por falta de vocaciones. Y cabría discutir también la razón de esa pobreza material y espiritual, ya que algunas de esas Comunidades, que han sabido resolver el problema, siguen hoy florecientes. Parece claro que las causas son profundas y generales, y nadie duda de que la situación deja mucho que desear. Se organizaron escuelas de párvulos, trabajos textiles, faenas de lavado y otras ocupaciones semejantes, que proporcionan alivio en la pobreza 
material y proporcionan medios de vida y de decoro. Hasta cierto punto se han logrado buenos resultados; pero eso no era lo principal. Esas almas, dedicadas a la contemplación, podrían remediar su pobreza viviendo con sus familias. Lo importante era el remedio a la pobreza espiritual, de la falta de entusiasmo religioso, del afán de «evangelización», de la implantación de ideales altos y claros, tal como lo leemos y vemos en las fundaciones de Sta. Teresa. Hoy hallaríamos muchos más medios de formación y de acción que en los tiempos en que vivió la Santa de Ávila.

Bastaría aducir aquí, como ejemplo edificante, la vida de la M. Guadalupe Vadillo, restauradora de nuestras Comunidades femeninas contemplativas de Méjico. Parece que ya en su noviciado se planteó el problema de la actividad que puede contraponerse a la contemplación. Siempre preocupada por buscar una actividad digna de lo que exige la contemplación, se of reció a la Jerarquía Eclesiástica, durante las persecuciones mejicanas, a guardar, imprimir, difundir la propaganda católica, que la Jerarquía no podía publicar por estar vigilada, perseguida o exiliada. Y cuando las persecuciones terminaron, fundó la casa que llamó Obra de Casiciaco, una casa organizada para promover la catequesis pastoral y reuniones de sacerdotes y movimientos apostólicos. Ella misma buscaba a las niñas y a las catequistas. Les proporcionaba becas, vestidos, residencia; y convertía la casa en un centro de irradiación espiritual, que todavía hoy conserva su prestigio.

Hoy han surgido ensayos tales como Taizé, no ya desde dentro, sino desde fuera del monasterio. $\mathrm{Y}$ estos ensayos nos obligan a reflexionar sobre la postura de san Agustín en el De opere monachorum y presentando su esquema de vida contemplativa.

1. Hay una vida contemplativa perfecta, que es la vida eterna. El amarla, desearla, pensar frecuentemente en ella como fuente y estímulo de la vida presente es ya en cierto modo vivir en la eternidad. Sin esa nostalgia amorosa, la vida contemplativa presente es un contrasentido, que no responde al ejemplo bíblico del ciervo herido que busca la frescura de la corriente de agua.

2. Contemplación imperfecta. Su ejercicio fundamental es la oración propiamente dicha; y ésta implica dos rasgos fundamentales: a) que la oración sea «espiritual», como vimos antes; b) que esa oración sea ilustrada, como lo vemos en la formación que san Agustín daba a sus monjes. Sin esas dos condiciones es difícil que un monasterio atraiga a los seglares ni les proporcione motivos de esperanza, coraje, trabajo, fe y caridad. Cuando Agustín comenzó su apostolado monástico, escaseaban las vocaciones más que hoy. Sin embargo, san Posidio testifica que Agustín dejó a la Iglesia unos monasterios llenos de excelentes monjes y unas diócesis llenas de un excelente clero. Pero todo esto exige una profunda obra de educación y formación. 
3. Contemplación semiimperfecta. La actual crisis de la vida contemplativa ha creado, como ya apuntamos, ciertas formas de evasión y escape cuyas consecuencias han sido muy discutidas (trabajo, parvularios, escuelas de costura, de tejidos, de artes y oficios, etc.). Así se ha solucionado el problema de la pobreza material, pero no el de la pobreza espiritual; y muchos maestros han protestado de que tales evasiones perjudican a la vida contemplativa o la contradicen. En nuestro caso se impone una reflexión sobre El trabajo de los monjes, en san Agustín. El Santo, apremiado por la contienda eclesiástica y por la exhortación del arzobispo Aurelio, da al problema un carácter exagerado, centrado en la conducta de san Pablo y en el trabajo manual de los monasterios bien organizados. Pero el fondo del problema nos permite ver que ni Agustín ni sus amigos trabajaron nunca manualmente. $\mathrm{Y}$ esos monjes, que se niegan a trabajar manualmente, alegan: no es ocio, sino un trabajo «semiimperfecto»; infundir a los seglares fe, esperanza y caridad, consolar, rehabilitar, reprender, etc. Acepta la «acción»; pero esa acción corresponde a lo que hoy llamaríamos Acción Católica, Cursillos de Cristiandad, Encuentro Matrimonial, Carismáticos, Palabra de Dios, Neo-Catecumenado, etc. Eso mismo pretenden las organizaciones del tipo Taizé. Pero es evidente que esa actividad intermediaria requiere una educación, formación y entrenamiento, cuidados especiales.

4. Vida mixta. Finalmente, aun aquellas actividades, que pueden considerarse como evasiones, reclaman también una educación especial para mantenerse en sus raíces contemplativas. Jesús reprendió a Marta, no por hacer algo mal, sino por hacer algo menos bueno. Y si meditamos este tema, veremos que Marta podía muy bien ocuparse del ministerio sin perder la presencia de Dios, ni la palabra de Cristo, ya que Dios anda también entre los pucheros, como decía santa Teresa. Agustín, en el libro El trabajo de los monjes, hace notar que, de un modo u otro, el trabajo material es también necesario; y que, bien organizado, puede remediar, no sólo la pobreza material, sino también la mental y espiritual. ¿Quién duda que muchos excelentes espíritus seglares son para los religiosos excelentes auxilios, estímulos, impulsos; $y$, a veces, un espejo en el que puede mirarse?

\section{DOCUMENTOS DE ACTUALIZACIÓN, OFRECIDOS COMO PISTAS.}

\section{Vaticano II}

Siendo Cristo enviado por el Padre, fuente y origen de todo apostolado de la Iglesia, es evidente que la fecundidad del apostolado seglar depende de su unión con Cristo, porque dice el Señor: Permaneced en mí y yo en vosotros. El que permanece en mí y yo en él, éste da mucho fruto, porque sin mí 
nada podéis hacer (Ioan 15, 5). Esta vida de unión íntima con Cristo en la Iglesia se nutre de auxilios espirituales, que son comunes a todos los fieles, sobre todo para la participación activa en la sagrada Liturgia, de tal forma los han de utilizar los fieles, que, mientras cumplen debidamente las obligaciones del mundo en las circunstancias ordinarias de la vida, no separen la unión con Cristo de las actividades de su vida, sino que han de crecer en ella, cumpliendo su deber según la voluntad de Dios... Nada debe ser ajeno a la orientación espiritual... según las palabras del Apóstol: todo cuanto hagáis de palabra o de obra, hacedlo todo en el nombre del Señor Jesús, dando gracias a Dios Padre por Él $(\mathrm{Col} 3,17)$. Una vida así exige un ejercicio continuo de la fe, de la esperanza y de la caridad... Los que pertenecen a alguna de las asociaciones o institutos aprobados por la Iglesia, han de esforzarse al mismo tiempo en asimilar fielmente la característica peculiar de la vida espiritual que les es propia» (Apostolicam Actuositatem, 4).

«Los presbíteros... reúnen a la familia de Dios, como una fraternidad alentada unánimemente y la conducen a Dios Padre por medio de Cristo en el Espíritu... para la edificación de la Iglesia... Atañe a los sacerdotes, como educadores en la fe, procurar que cada uno de los fieles sea conducido en el Espíritu Santo... a la caridad y libertad con que Cristo nos liberó. De poco servirán las ceremonias, por hermosas que sean, o las asociaciones aunque florecientes, si no se ordenan a formar a los hombres para que consigan la madurez cristiana... Ayudarán los presbíteros para poder averiguar qué hay que hacer, o cuál sea la voluntad de Dios en los mismos acontecimientos, grandes o pequeños. Enséñense también a los cristianos a no vivir sólo para sí... Ponga cada uno al servicio del otro el don que recibió y cumplan así todos cristianamente su deber en la comunidad humana. De una manera especial a los pobres y a los más débiles, a los jóvenes, a los cónyuges y padres de familia... enfermos, agonizantes, visitándolos y confortándolos. Edifiquen la comunidad cristiana, en la Iglesia local y en la Iglesia universal..., preparando a todos los hombres el camino hacia Cristo... La raíz y quicio es la celebración de la Eucaristía... Además, la comunidad eclesial ejerce por la caridad, por la oración, por el ejemplo y por las obras de penitencia una verdadera maternidad respecto a las almas que debe llevar a Cristo. Porque ella es un instrumento eficaz, que indica o allana el camino hacia Cristo y su Iglesia a los que todavía no creen, que anima también a los fieles, los alimenta y fortalece para la lucha espiritual... Los presbíteros empeñan toda su labor en conseguir el incremento espiritual del Cuerpo de Cristo» (Presbyterorum Ordinis, 6).

«Todos los presbíteros son enviados, ya ejerzan el ministerio parroquial o interparroquial, ya se dediquen a la investigación o a la enseñanza, ya realicen trabajos manuales..., ya desarrollen otras obras apostólicas u ordenadas al 
apostolado. Todos tienden ciertamente a un mismo fin, a la edificación del Cuerpo de Cristo» (Presbyterorum Ordinis, 8).

«El futuro misionero ha de prepararse con una formación característica espiritual y moral para un empeño tan elevado. Bebe ser capaz de iniciativas, constancia para continuar hasta el fin lo comenzado, perseverancia en las dificultades, ciencia y fortaleza para sobrellevar la soledad, el cansancio y el trabajo infructuoso. Se presentará a los hombres con apertura de alma y grandeza de corazón... El misionero sea hombre de oración, inflámese en espíritu de fortaleza. Lleno de fe viva y esperanza firme... Cumpliendo con Cristo la voluntad del Padre, continuará su misión bajo la autoridad jerárquica de la Iglesia y cooperará al misterio de la salvación» (Ad gentes, 25).

«Procuren (los religiosos) fomentar en todas las circunstancias la vida escondida con Cristo en Dios ( $\mathrm{Col} 3,3)$, de donde dimana y se estimula el amor del prójimo para la salvación del mundo y edificación de la Iglesia. Esta caridad, por su parte, anima y dirige al mismo cumplimiento de los consejos evangélicos. Por lo cual han de practicar asiduamente el espíritu de oración e incluso la oración misma, bebiendo en las limpias fuentes de la espiritualidad cristiana. Tengan continuamente en sus manos la Sagrada Escritura, para conseguir con su lectura y meditación el sublime conocimiento de Cristo (Filp 3, 8). Desarrollen interior y exteriormente la sagrada Liturgia, máxime el sacrosanto misterio de la Eucaristía, según la mente de la Iglesia, y nutran su vida espiritual con este riquísimo venero» (Perfectae caritatis, 6).

\section{Religiosos de apostolado}

«Hay dones diferentes (Rom 12,5). Pero es uno y el mismo Espíritu (1Cor $-12,4)$. Toda su vida ha de estar saturada de espíritu apostólico y toda su obra apostólica ha de estar animada por el espíritu religioso... Su acción apostólica ha de proceder de la unión íntima con Cristo. De donde dimana el acrecentamiento de la caridad para con Dios y para con el prójimo» (Perfectae caritatis, 8).

Roma, 25 de julio de 1985. En el Congreso agustiniano, que tuvo por título: San Agustín y la evangelización.

(Ponencia del P. Lope Cilleruelo) 